\title{
Response of the Digitaria sanguinalis (L.) Scop. to the soil salinity - a greenhouse experiment
}

\author{
Božena Šerá, Iveta Hrušková, Markéta Nováková \\ Institute of Nanobiology and Structural Biology of GCRC, Na Sádkách 7, \\ České Budějovice, CZ - 37005, Czech Republic \\ e-mail:sera@usbe.cas.cz
}

\begin{abstract}
Summary. Large crabgrass is not registered in the Ellenberg's list of halophyte species, but it growths in salt contaminated soil along roads. Our manipulative experiment in greenhouse was focused on growth activities of Large crabgrass in salt soil condition. Saline solutions of sodium chloride were $0,0.12,0.25,0.50,0.99$, and $1.96 \%$. The experiment confirmed the successful growth and development of Large crabgrass in soil contaminated with salt $(0.12 \%$ of $\mathrm{NaCl})$. The inhibitive effect was found in soil with $\mathrm{NaCl}$ concentration more than $0.12 \%$.
\end{abstract}

Key words: plant growth, soil contamination, weed.

\section{Introduction}

Large crabgrass (Digitaria sanguinalis (L.) Scop) is a summer annual species, having a prostrate or ascending growth habit with stems that root at the nodes. Stems are prostrate, spreading, branched, and rooting at the nodes. Fibrous root system corresponds with Poaceae family. It is non-native, invasive species in Europe (Jehlík 1998), which produce

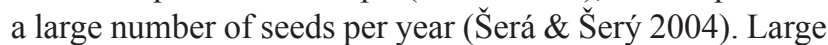
crabgrass is considered to be an aggressive weed in some subtropical crops, mainly sugarcane, corn and soya. In Europe, it is a troublesome weed in corn (Mikulka et al. 2005). Large crabgrass has spread very quickly along all class roads (motorways with median stripes; roads of the I, II and III classes) in the Czech Republic (Šerá 2008). It is way, why this species probably belong to dangerous weed that could spread to agricultural areas via road network.

\section{Materials and methods}

The soil substrate consisted of two parts: a horticulturalflower potting soil (purchased from Rašelina a.s., Soběslav, Czech Republic) mixed with sand in a 2:1 ratio. The parts of the substrate used were sieved through a screen (mesh $3 \times 3 \mathrm{~mm}$ ). The soil substrates were neither fertilized nor sterilized. The soil mixture was enriched with pulverized limestone ( 3 g per 5 l) and $14 \mathrm{~g}$ of dried knotweed leaves were added per $1 \mathrm{l}$ of soil substrate. Plastic flowerpots of size $4 \times 4 \times 6 \mathrm{~cm}$ were filled with $30 \mathrm{ml}$ of the substrate and placed onto a watering tray.

The tested plants were collected on their field localities in the vicinity of České Budějovice, Czech Republic during spring 2010. Only undamaged vital seedlings of Large crabgrass were collected. One seedling was planted in each flowerpot. When the seedlings started to grow, the treatments (A-E) began to carry out. The soil substrate was contaminated by saline solution of $\mathrm{NaCl}$ : A $0.12 \%$, B $0.25 \%$, C $0.50 \%$, D $0.99 \%$ and E $1.96 \%$. Control sample 
Table 1. Growth characteristics of Large crabgrass (Digitaria sanguinalis) cultivated in saline soil. Used saline solution of NaCl: $\mathrm{K}-0 \%, \mathrm{~A}-0.12 \%, \mathrm{~B}-0.25 \%, \mathrm{C}-0.50 \%, \mathrm{D}-0.99 \%$ and $\mathrm{E}-1.96 \%$.

\begin{tabular}{|c|c|c|c|c|c|c|c|c|c|c|c|c|}
\hline \multirow{2}{*}{ Treatment } & \multicolumn{3}{|c|}{ Root length (mm) } & \multicolumn{3}{|c|}{ Shoot length (mm) } & \multicolumn{3}{|c|}{ Root weigth (mg) } & \multicolumn{3}{|c|}{ Shoot weigth (mg) } \\
\hline & Mean & SD & HSD & Mean & SD & HSD & Mean & SD & HSD & Mean & SD & HSD \\
\hline K & 124.00 & 20.63 & a & 476.08 & 37.37 & a & 0.022 & 0.006 & $\mathrm{a}$ & 0.087 & 0.033 & $\mathrm{a}$ \\
\hline A & 130.00 & 29.43 & a & 468.75 & 44.57 & $\mathrm{a}$ & 0.021 & 0.007 & $\mathrm{a}$ & 0.091 & 0.026 & $\mathrm{a}$ \\
\hline B & 94.50 & 27.45 & $\mathrm{~b}$ & 413.00 & 50.95 & $\mathrm{~b}$ & 0.014 & 0.005 & $\mathrm{~b}$ & 0.086 & 0.029 & $\mathrm{a}$ \\
\hline C & 111.67 & 26.75 & a & 384.42 & 45.30 & bc & 0.011 & 0.005 & $\mathrm{~b}$ & 0.068 & 0.021 & $\mathrm{a}$ \\
\hline $\mathrm{D}$ & 75.50 & 11.89 & c & 345.25 & 66.00 & c & 0.013 & 0.003 & $\mathrm{~b}$ & 0.077 & 0.018 & $\mathrm{a}$ \\
\hline $\mathrm{E}$ & 56.33 & 17.24 & c & 110.25 & 17.44 & d & 0.005 & 0.001 & c & 0.023 & 0.008 & $\mathrm{~b}$ \\
\hline
\end{tabular}

(K) was without saline contamination. For each assay (K, A-E), 144 flowerpots were prepared (132 flowerpots for using and 12 flowerpots as reserve).

The Large crabgrass plants were incubated in a greenhouse at $18^{\circ} \mathrm{C}$ during the day and $10^{\circ} \mathrm{C}$ at night for three months. The soil was regularly irrigated on the trays with the same amount of water. In time measurement data, 12 plants were removed from the flowerpots and measured. The morphological characteristics were registered: length and weight of root and shoot, number of leaves and inflorescences, ear weight.

One-way ANOVA and post hock comparison of Tukey's HSD test were used for data processing to evaluate the influence of each saline soil on growth and development of Large crabgrass plants. All the statistical tests were performed at the 0.05 level of statistical significance.

\section{Results and discussion}

Analysis of variance results revealed that increasing salinity reduces growth of Large crabgrass plants. Significant differences between control sample and treatment samples were found (Tab. 1). No differences were calculated between control sample and plants growing in saline soil with saline solution of $0.12 \% \mathrm{NaCl}$. The strongest growth inhibition was found in soil salinity of $1.96 \%$. The plants were small, dried biomass was low, leaves was greyish green, but some plants flowered and produced seeds.

Soil salinity is a widespread problem that restricts plant species growth and agriculture production in many areas (Apse et al. 1999). Salt tolerance is the ability of plants to survive and grow under saline soil conditions. Salt tolerance is a variable trait that depends on many factors, above all on a taxonomic affiliation (Volkmar et al. 1998). Plants generally vary in response to soil salinity and Large crabgrass is not registered as a salt-tolerant plant species (Ellenberg et al. 1992).
Our preliminary results from manipulative experiment in greenhouse show that the Large crabgrass is able "to grow normally" in a contaminated saline soil, if the concentration of $\mathrm{NaCl}$ is $0.12 \%$. Higher concentration of $\mathrm{NaCl}$ is closed with significant lower length/weight of root and shoot. Some of the plants growing in soil with concentration of $1.96 \% \mathrm{NaCl}$ flowered and produced seeds.

\section{Acknowledgements}

This paper was supported by project No. OC10032 of the MEYS (MŠMT), as well as by the research plan No. AV0Z60870520.

\section{References}

Apse M. P., Dharon G. S., Snedden W. A. \& Bumerold E., 1999, Salt tolerance conferred by overexpression of a vacuolar $\mathrm{Na}+/ \mathrm{H}+$ antiport in Arabidopsis, Science 285: 1256-1258.

Ellenberg H., Weber H. E., Düll R., Wirth V., Werner W. \& Paulißen D., 1992, Zeigerwerte von Pflanzen in Mitteleuropa, 18: 9-160.

Jehlík V., 1998, Cizí a expanzivní plevele České republiky a Slovenské republiky [Alien and expansive weeds of the CR and SR], Praha, Academia.

Mikulka J. \& Kneifelová M. (eds.), 2005, Plevelné rostliny [Weed plants], Praha, Profi Press.

Šerá B., 2008, Road vegetation in Central Europe - an example from the Czech Republic, Biologia 63: 1081-1084.

Šerá B. \& Šerý M., 2004, Relation between number and weight of seeds and reproductive strategies in herbaceous plants, Folia Geobotanica 39: 27-40.

Volkmar K. M., Hu Y. \& Steppuhn H., 1998, Physiological responses of plants to salinity: a review, Canadian Journal of Plant Science 78: 19-27. 